\title{
The value of religious character education in children's stories is We are Superstars by Nadia Shafiana
}

\author{
Ahmad Mansur Efendi ${ }^{1}$, Witra Amelia ${ }^{2}$, Yenni Hayati ${ }^{3}$ \\ $\left\{\right.$ mansurefendi91@gamil.com ${ }^{1}$,witraamelia@student.ac.id ${ }^{2}$,yenn.hayati@yahoo.com $\left.{ }^{3}\right\}$ \\ 1,2,3Universitas Negeri Padang, J1. Prof. Dr. Hamka Air Tawar Padang Sumatera Barat 25131, \\ Indonesia
}

\begin{abstract}
This study aims to reveal the values of religious education contained in the children's story We are Superstars by Nadia Shafiana. This type of research is qualitative research with a descriptive approach. The data of this study is the exposure of the narrator / figure, the words of the character and the actions of the characters in the child's story. The data collection techniques are (1) Reading and understanding children's stories, (2) Recording the words and sentences of the narrator's exposure and / or the characters' stories and actions that can be formulated as children's characters, (3) Inventorying data according to the object of research, based on the format data inventory. The data analysis techniques are (1) data reduction, (2) data presentation, (3) classifying data, (4) interpreting data, and (5) drawing conclusions. The results of his research are 42 religious characters found in the stories of the children studied. the value of religious character education with indicators of believing in God amounts to 16 data $(38.1 \%)$, the value of religious education with indicators of carrying out orders and avoiding God's prohibitions is 11 data (26.2\%), the value of religious education with a trust indicator is 5 data (12\%) and the value of religious education with thankful and sincere indicators is 10 data (23.9\%).
\end{abstract}

\section{Keywords: character education, religus, children's stories}

\section{Introduction}

Education is a media to educate the life of the nation and to build a national order with the values of intelligence, sensitivity, honesty and concern for the life of the nation and state. Education is a strong milestone for alleviating poverty, advancing knowledge, resolving the issue of ignorance, and resolving all the problems of the nation that have been happening. The role of education is clearly significant and central because education provides the opening and expansion of knowledge so that this nation is truly literate towards the life of the nation and state. Education is presented to usher in this nation into a civilized and cultured nation. Education is a process that is wider than the process that takes place in the school. Education is an essential social activity that enables complex societies (Al Arifin, 2012).

In modern society, the function of education undergoes a process of specialization and institutionalization with formal education, but is still related to the process of informal education outside of school. In law number 20 of 2003 concerning the national education system article 3 states that: National education functions to develop capabilities and assist the dignity of the nation's dignity in order to educate the nation's life, aiming at the development 
of students' potential to be faithful and devoted to God the Almighty Esa, noble, healthy, knowledgeable, capable, creative, independent, and a democratic and responsible citizen.

Research on character education through literary work has been carried out, among others, (Waryanti, 2015), (Hapsari, 2017), (Hermansyah, 2017), and (Wulandari, 2015) the results of his research concluded that literary works can be a good medium for planting characters. Because through literary works children not only get pleasure but also get teladana from the characters in the story.

Zainun (2015:36) said that character education is a system of planting values (characters) to school people which includes knowledge, awareness or willingness, and actions to implement values, both towards God Almighty (YME), self, fellow environment, and nationality so that we become our human beings. Building student character education is a learning value to face future educational challenges. Character education built by a nation is closely related to the strength of the nation itself. National character education carried out at the school level will give birth to a good society, and have relations and behavioral norms that inspire shared life, in the form of trust among fellow citizens, this will lead to a relationship of mutual trust in all aspects of life.

Prayitno and Afriva Khaidir (2011:130-139) formulate five focus values of character education that come from the development of components or elements of human dignity and values (HMM) and values of Pancasila. The values of character education are (1) faith and devotion to God Almighty, (2) honesty, (3) intelligence, (4) resilience, (5) caring. Then Prayitno and Afriva Khaidir specifies those values in the form of a more specific concept and more concrete in the appearance of behavior.

The details referred to in the five characters above are, (1) faithful and devoted, among others: religion, namely believing in God Almighty, carrying out orders and avoiding the prohibition of God in accordance with the religion adhered to, trustworthy, grateful and sincere, (2) being honest : say what is, do the truth, defend the truth, be responsible, fulfill responsibility and rights, be generous and hold promises, (3) be smart, among others: active or dynamic, directed or logical thinking, analysis and objective, able to solve problems or find solutions, be creative or create new things, think forward, be consistent, think positively and openly, (4) tough, among others: thorough, patient or self-controlled, disciplined, resilient or not desperate, hard working, skilled, productive, oriented added value, dare to sacrifice, hold the test, dare to take risks and maintain $\mathrm{k} 3$ (completeness, health and safety), (5) care, among others: comply with regulations or applicable laws, manners, loyal by obeying orders in accordance with duties and obligations, democracy, kinship, mutual cooperation, tolerance, deliberation, orderly, peaceful or anti-violence. Forgiving and maintaining confidentiality. .

The purpose of this descriptive study is to make a systematic, factual and accurate decryption, description or painting of the facts, the characteristics and the relationships between the phenomena investigated. Descriptive analysis method is a method that is carried out by describing the facts which are then followed by analysis. This method does not merely describe but also provides understanding and explanation (Hudayat: 2007).

\section{Method}

This type of research is a qualitative research and uses descriptive analysis methods. Descriptive method is a method in examining the status of a group of people, an object, a set of conditions, a system of thought or a class of events in the period of the sacred. Moleong (2010) qualitative research is research that intends to understand the phenomenon of what is experienced by the subject of research such as behavior, perceptions, motivations, actions, 
etc., holistically and with descriptions in the form of words and language, in a specific context natural and by utilizing various scientific methods.

Moleong (2010) explains that qualitative research is research that produces descriptive data in the form of written or oral words from people and observable behavior. Moleong also argues that qualitative research is the collection of data in a natural setting by using natural methods and carried out by people or researchers who are naturally attracted. According to Jane Richie (in Moleong, 2009: 6) qualitative research is an attempt to present the social world, and its perspective in the world in terms of concepts, behaviors, perceptions, and problems about the human being studied.

This descriptive method is used to see and describe the construction of children's character in the children's story that became this study. Produce data in the form of words not in the form of numbers. So this study describes the forms of children's character education values, which are contained in the children's story We are Superstars by Nadia Shafiana.

The data of this study is the exposure of the narrator / figure, the words of the character and the actions of the characters in the child's story. The data collection techniques are (1) Reading and understanding children's stories, (2) Recording the words and sentences of the narrator's exposure and / or the characters' stories and actions that can be formulated as children's characters, (3) Inventorying data according to the object of research, based on the format data inventory. The data analysis techniques are (1) data reduction, (2) data presentation, (3) classifying data, (4) interpreting data, and (5) drawing conclusions

\section{Result and discussion}

\subsection{Results}

The results of this study are the acquisition of the value of religious education in the children's story We are Superstars. Then there are some religious characters here representing indicators such as indicators of believing in God, carrying out orders and avoiding the prohibitions of God, trustworthy, grateful and sincere. The results of this study will be described as follows.

Table 1. Values Character Education in Children Stories We are Superstars

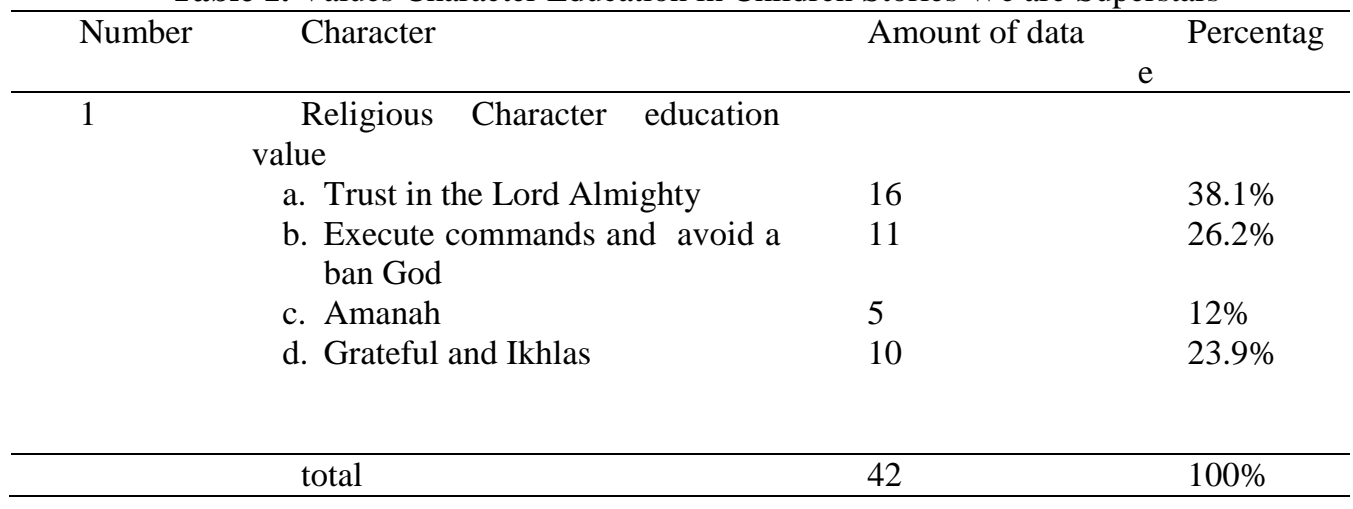

\subsection{Discussion}

Religious Character Education in children's stories We are Superstars:

\section{a. Religious character with indicators of trust in God.}


"Before we start the program tonight, let's pray, hopefully everything will go smoothly. Praying starts, "Tama led our prayers with a large team. "Praying is complete."

One indicator of the value of education in religious characters is believing in God. We as humans or creatures of God are indeed obliged to believe and believe in the existence of God. And education about faith and trust in the existence of God is very well introduced to children from an early age. The concept of the character of believing in God is in the following quote. From the quote from the figure above, it can be seen that the characters in this children's story have believed and believed in the existence of God. We can see this from their daily activities which always do something by beginning with prayer. Like the figure of Tama above leading a prayer when going to start music practice with the hope that his latiah will be smooth and not obstruction.

\section{b. Indicators carry out orders and stay away from prohibitions}

Arriving at home, I immediately took a shower and prayed Maghrib, only after that I went to the dining table to fill my stomach that I had been hungry ... "

We as religious people have an obligation to carry out religious orders. The religious orders such as carrying out worship, doing good, helping each other, preventing repercussions and inviting good. The concept of carrying out orders and avoiding prohibitions is contained in the quotation as follows: The above quotation explains that the figure of Ana "I immediately took a shower and prayed Maghrib" when I returned home she immediately took a shower and did Maghrib prayer. He prays because Ana's figure is aware and believes that prayer is an obligation that must be carried out. The figure Ana prioritizes carrying out God's commands rather than eating first even though she is already hungry.

\section{c. Indicator of Trust}

"You see how serious you are to turn on the school band. Starting today, you officially hold an extracurricular band, "said Pak Budi.

In addition to God ordering us to always carry out orders and stay away from prohibitions, we are also instructed to keep the mandate as well as possible. The above quote explains that the official headmaster of the school held an extracurricular school band because he saw the sincerity of Ana and friends in practicing music. Then Ana and friends were happy and serious in training. In this case Ana and friends because of their persistence in practicing music, the headmaster gave the mandate of holding extracurricular music.

\section{d. Thankful and Sincere Indicators}

"The favorite band is ..." Everyone wants to win, I know that. But at least, give Takana a chance to increase our enthusiasm. I really hope, even exceed the expectations of other participants. Much bigger than them. "It is ..." The MC repeated again. After a long sigh, his eyes glanced at the audience who seemed to hope, "The favorite band is ... Bluishiash Band!" They cheered and our faces were sad even though we were roomy to accept as an experience.

The above quotation explains that the characters Ana and friends sincerely and broadly accept the announcement of the jury whose results turned out to be the winners not them. Although they really hope that they will be the champion. One of God's commands is that we must always be grateful for everything we get, even though sometimes our hearts feel less able to accept it. One of the ways we are grateful is by saying the word hamdalah or 
Alhamdulillahirobbil'alamin which means all praise is to Allah who controls nature. Grateful can also be done by doing good and avoiding evil.

This study complements previous research conducted by [11] with the topic Development of socialization skills and character education training is an important part of children's academic success. Character education efforts may be effectively applied and rigorously on a scientific basis. Schools must focus on the characters that support the regular curriculum.

In addition to completing research findings, [12] also conducts research on character education that explains the story of ancient Balinese tradition; stories can be used as a medium to start character education early on. Storytelling can build a warm relationship between parents and early childhood, therefore character education can be transferred easily. The Baka Pedanda story contains religious character values; this will cause problems. Because they have killed, all the fish found in the lake then the baka will receive a death sentence by the crab. The character of education can be through the story of Pedanda Baka sent at home by parents to children from an early age and at school by teachers for students. Character education can be given not only at home but also at school because during school age in the world of children. Through the Banda Story Baka, character education for children from an early age can easily be done, because in the story there will be found a figure who can be a role model for children from an early age in action.

\section{Conclusion}

From the results of the above research it can be concluded that in the children's story We are Superstars by Nadia Shafiana found the value of religious character education with indicators of trust in God totaling 16 data $(38.1 \%)$, the value of religious education with indicators of carrying out orders and avoiding God's prohibitions totaling 11 data $(26.2 \%)$, the value of religious education with trust indicators is 5 data (12\%) and the value of religious education with indicators of thankful and sincere amounts to 10 data $(23.9 \%)$.

Based on the analysis and conclusions that the author has done, the author gives advice to readers and enthusiasts of literature to conduct a more in-depth study of literary works, especially about the value of religious character education, the authors hope this research can contribute to further researchers and authors as well. hoping that with this research, it should be able to provide knowledge and understanding for readers regarding literary works, especially in the value of religious character education in literary works.

\section{Acknowledgements}

The author thanks the supervisor who has taken the time in completing this article and the authors say to the contributors for the criticism that has been given.

\section{References}

[1] Al Arifin, A H. 2012. Implementasi Pendidikan Multikultural dalam Praksis Pendidikan di Indonesia. Jurnal pembangunan Pendidikan: Fondasi dan Aplikasi 72. Vol. 1. No. 1. Juni 2012.

[2] Waryanti, Endang. 2015. Pembelajaran Sastra Berbasis Karakter, dalam Jurnal Buana Sastra Tahun 2, No, 2. Agustus 2015

[3] Hapsari, Z. 2017. Dongeng sebagai pembentuk Karakter Anak. Jurnal kajian Perpustakaan dan Informasi. Vol 1 No 1 -April 2017(21-29). 
[4] Hermansyah, A K. 2017. Nilai-nilai Kemanusiaan dalam buku 100 Cerita Anak Pilihan dan Kesesuaiannya Sebagai Bahan Pembelajaran Sastra di SD/MI dalam Jurnal Alibtida:Jurnal Pendidikan Guru MI (2017) Vol 4 (1): 17-28

[5] Wulandari, R A. 2015. Sastra dalam Pembentukan Karakter Anak, dalam Jurnal Edukasi Kultura Vol. 2 No. 2 September 2015

[6] Zainun, Agib. 2015. Pendidikan Karakter Suatu Sistem Penanaman Nilai. Yogyakarta: Pustaka Pelajar.

[7] Prayitno dan Afriva Khaidir. 2011. Model Pendidikan Karakter Cerdas. Padang: UNP Press

[8] Hudayat. 2007. Jenis dan Metode Penelitian. Yogyakarta: Pustaka Pelajar.

[9] Shafiana, Nadia. 2019. We Are Superstars. Bandung: Mizan Pustaka.

[10] Moleong,L. J. (2010). Metode penelitian kualitatif. Bbandung: Remaja Rosdakarya.

[11] Aynur Pala . 2011. International Journal Of Social Sciences And Humanity Studies Vol 3, No 2, 2011 ISSN: 1309-8063

[12] Ni Nyoman Sudiani. 2017. International Journal Of Hindu Sciences And Religious Studies Vol 1, No 1 